\title{
Unable to Accommodate Disability or Language
}

National Cancer Institute

\section{Source}

National Cancer Institute. Unable to Accommodate Disability or Language. NCI

Thesaurus. Code C106461.

Unable to meet the requirements of an individual's disability or language. 